\title{
Critical language teaching in a dynamic language policy terrain: lessons from the Brazilian Science without Borders student mobility programme
}

\section{Ensino da língua crítica em um campo de políticas linguísticas dinâmica: lições do programa brasileiro de mobilidade estudantil Ciência sem Fronteiras}

Jonathan Luke*

*York University, Toronto, Ontario / Canada

jonathan.r.luke@gmail.com

\begin{abstract}
This article reports on a case study of English language learning in higher education, considering the impact of language policies embedded within a mobility scholarship programme on the practices of language teachers. Based on a larger ethnographic study following the experiences of several undergraduate members of one cohort of Brazil's Science without Borders programme for students in science and technological fields, this article describes how several language teachers engaged with the power relations of the frequently shifting policy terrain of the programme. It concludes with a discussion of possibilities for teachers in similar situations who endeavour to take a critical approach to language teaching and explores some of the tactics they might employ against those policies which they see as incompatible with their practices.
\end{abstract}

KEYWORDS: English language learning; higher education; language policy.

RESUMO: Este artigo relata um estudo de caso sobre a aprendizagem da língua inglesa na educação superior, considerando o impacto de políticas linguísticas embutidas em um programa de mobilidade nas práticas de professores de inglês. Com base em um estudo etnográfico mais amplo e seguindo as experiências de vários alunos participantes de um edital do programa brasileiro Ciência sem Fronteiras - destinado a graduandos de áreas tais como engenharia, tecnologia e ciências exatas - este artigo descreve como vários professores de inglês se engajaram em frequentes relações de poder que perpassam o programa. Conclui-se com uma discussão sobre possibilidades para professores em situações semelhantes que se esforçam para adotar uma abordagem crítica no 
ensino de línguas, bem como exploram-se algumas estratégias que podem ser empregadas contra as políticas consideradas incompatíveis com suas práticas.

PALAVRAS-CHAVE: aprendizagem da língua inglesa; educação superior; políticas linguísticas.

\section{Introduction}

Ever-increasing global flows of students - most often from the Global South to the Global North - present considerable challenges for language educators in both host and sending nations, given the fact that the majority of these students travel to study in a second language such as English (ALTBACH, 2007). For many international students, language learning constitutes a key component of the study abroad experience, and to address the need for second language learning, student mobility initiatives such as Brazil's Ciência sem Fronteiras (Science without Borders, or SWB) programme often involve language acquisition planning and policies as embedded components in larger education and mobility policies. Due to the collaborative nature of mobility programmes, this language policy and planning (LPP) typically involves a broad range of institutional, regional, national, and international agents across a range of scale levels (BLOMMAERT, 2010), in intricate, hierarchical and at times unpremeditated relations with one another. As micro-level agents, teachers are often left out of planning and policy-making processes, despite the fact that the classroom typically constitutes the ground zero of LPP implementation. They are thus routinely required to negotiate the scant wiggle room they are allotted by a complex assemblage of regulations, testing requirements, curricula and other planned and unexpected features produced by other agents and stakeholders (DIALLO; LIDDICOAT, 2014; JOHNSON; JOHNSON, 2015).

Drawing on a larger ethnographic study of student experiences with language learning on the SWB mobility scholarship programme (LUKE, 2017), ${ }^{1}$ this paper focuses on the policy conditions for several language teachers at one Canadian university in the case of the SWB cohort commonly referred to as the Portugal cohort. The students in this group had initially expressed a preference for studying in Portuguese language medium of instruction, in universities in Portugal, and were subsequently

${ }^{1}$ A PhD dissertation supervised by Dr. Eve Haque at York University. 
presented the opportunity by CAPES (Coordenação de Aperfeiçoamento de Pessoal de Nivel Superior, or Coordination for the Improvement of Higher Education Personnel, one of the Brazilian government agencies involved in managing the SWB programme), to study elsewhere in the world provided that they acquire a second language (for the large majority, English). After providing brief explanations of how I conceptualize language policy in this study and how it relates to the practices of language teachers, as well as some methodological considerations, I present a timeline of the experiences of the Portugal cohort learning English in Canada at one university, against a frequently shifting and often opaque policy backdrop. I then describe the ways in which four teachers in this university's language and academic preparation programme perceived and reacted to these policies. I conclude with a discussion of the implications that this case presents for teachers in similar situations who endeavour to take a critical approach to their language teaching, and suggest some of the ways they might be able to engage in what Foucault refers to as counter-practice/counter-conduct (DAVIDSON, 2011; FOUCAULT, 2009), or tactics of resistance against those aspects of the policy assemblage which they see as incompatible with their own approaches to language teaching (HAQUE, 2007), while also reflecting on the significant constraints they face.

\section{Critical language teaching and language policy}

Despite the fact the interface between approaches to critical language teaching (CLT) and language policy and planning (LPP) has been the subject of considerable scholarship by researchers and practitioners in recent years (e.g., CANAGARAJAH, 2005; CHUN, 2015; HAWKINS; NORTON, 2009; JOHNSON, 2013; PENNYCOOK, 2001; TOLLEFSON, 2006), empirical investigation into exactly how they interact with one another in a practical manner has been subject to far less attention, and this interaction remains to be explored extensively (DIALLO; LIDDICOAT, 2014; but see articles collected in RAMANATHAN; MORGAN, 2007; STRITIKUS, 2003, for some noteworthy exceptions). This is, at least in part, due to the fact that LPP research has its origins in examining top-down approaches to language governance at the level of the state in the planning of national languages, and more recently, questions surrounding promotion and rights for minority languages and their speakers in education and other public domains. In 
contrast, CLT typically focusses on the praxis of individual teachers in particular sociopolitical contexts, and their efforts to address social and educational inequalities in these spaces (e.g., HAWKINS; NORTON, 2009). However, current conceptions of LPP have broadened from earlier work analysing historical documents and official texts, to also include "unofficial, covert, de facto, and implicit mechanisms, connected to language beliefs and practices, that have regulating power over language use and interaction within communities, workplaces and schools", as well as taking a perspective on policy as a dynamic process rather than or in addition to simply a static set of regulative texts (JOHNSON, 2013, p. 9). One aspect of this broader conception which has particular significance in this study is in the area of language testing, which, in the absence of official language policies, often has the ability to function as a form of de facto policy (SHOHAMY, 2006). Menken (2008, p. 160) highlights these potentially covert qualities of language testing, arguing that testing often constitutes a form of LPP, "even though it is not presented as such and is rarely seen in this light".

A second move in recent LPP research is the increasing use of ethnography, which, as Johnson (2013, p. 44) defines it, provides both "a method and theory for examining agents, contexts, and processes across the multiple layers of language policy creation, interpretation and appropriation". Canagarajah (2006, p. 154) qualifies this definition, noting that ethnography facilitates the possibility of listening in at the ground level to the "indistinct voices and acts of individuals in whose name policies are formulated" and presumably also to those who are tasked with implementing or brokering policies at the micro level, and who draw on or negotiate local knowledge in order to complete this work.

Reflecting on these individuals in their various subject positions as intended objects or conduits of policy provides a useful link between thinking about LPP critically, and the practice of critical language teaching. A central concern in scholarship on critical language teaching is that of constraints and possibilities for learner and teacher agency (e.g., HAQUE, 2007; VARGHESE et al., 2005). Similarly, a shift towards thinking about policy as a locally situated process reflected in practice also foregrounds these questions of agency. In his call for reclaiming language policy as a local practice, Canagarajah (2005, p. 4) highlights the ways in which local practitioners often "develop a knowledge of accomplishing their work in ways that are not acknowledged or recommended by the authorities or 
experts", attending to the gaps that open up between official policies as opportunities for them to complete this work in. At the same time, recent LPP research recognizes the constraining and pervasive nature of policy as governmentality (FOUCAULT, 2009), and the multiplicity of ways in which governmental power acts on its subjects, from the dissemination of discourses or dominant ideologies delineating the possible field of actions, through to a complex range of micro-strategies of decentralized control by the self and others. Thinking about the relations between LPP and critical language teaching in this way invites investigation into not only how students engage with these complex policy assemblages and the ways in which, as policies, they aim to conduct subjects, but also how teachers might conduct themselves in navigating conditions and constraints placed on their practices.

\section{Methodological considerations}

As stated above, this article draws on a larger ethnographic study of student experiences with language learning as part of the SWB mobility scholarship programme. For this study, I conducted fieldwork following a focal group of nine student members of the Portugal cohort through their language learning and academic studies for a period of twelve months (February 2014 - January 2015). Further information about these participants can be found in Table 1 (all names are pseudonyms).

TABLE 1 - Information about research participants

\begin{tabular}{l|c|c|l|c|l|l}
\hline Name & Gender & Age & Field of Study & $\begin{array}{c}\text { Home } \\
\text { University }\end{array}$ & $\begin{array}{c}\text { Home } \\
\text { Region in } \\
\text { Brazil }\end{array}$ & $\begin{array}{c}\text { Duration of } \\
\text { Sojourn in } \\
\text { Canada }\end{array}$ \\
\hline Ana & F & 22 & Engineering & Private & Southeast & 12 months \\
\hline Bruna & F & 26 & Information Systems & Private & Southeast & 8 months \\
\hline Clara & F & 23 & Health Sciences & Public & Northeast & 12 months \\
\hline Jessica & F & 27 & Engineering & Private & Southeast & 16 months \\
\hline Daniel & M & 21 & Information Systems & Public & Northeast & 16 months \\
\hline Fernanda & F & 23 & Health Sciences & Public & South & 16 months \\
\hline Lucas & M & 24 & Health Sciences & Private & South & 16 months \\
\hline Thiago & M & 22 & Computer Science & Private & Southeast & 16 months \\
\hline
\end{tabular}


Fieldwork was divided into two phases. For the first four months of my fieldwork, the students completed intensive non-credit English language study and academic preparation at the language centre in a large public university in a major Canadian metropolitan area. During this phase (which is the focus of this article) I regularly observed two separate classes, and frequently socialized with the students between classes and in the cafeteria (approximately 30 hours). I conducted impromptu and formal interviews with the students frequently, and audio recorded all formal encounters (approximately 40 hours). At the same time, I conducted one-time interviews with three instructors at the language centre, including the two instructors of the classes I observed, while a visiting Brazilian colleague interviewed a fourth. I also interviewed several other stakeholders, including a senior administrator at the university's international office, as well as a project manager at the Canadian Bureau of International Education (CBIE), an administrative partner organization of the federal government which managed the scholarships of the student members of the Portugal cohort on behalf of Brazil and CAPES. A second phase followed the students through the duration of their time in Canada, where they were placed at four different universities throughout the country, and in two cases, were recalled to Brazil as they were not accepted into academic study in Canada. Alongside this fieldwork, I collected a broad range of official and un-official policy documents from governmental and institutional sources, as well as media reports about the programme from both the Brazilian and Canadian press. In this article, I first draw primarily from these documents and media reports in order to tell the narrative of the Portugal cohort's time in Canada, and subsequently draw from the interviews with four teachers from the language centre, in order to gain insight into their perspectives on the shifting policy landscape in this particular case. As classroom observations focused on the students, in this article, in large part I attend to the ways in which teachers reflected on their engagements with LPP, rather than my own observations and interpretations of what happened in their classrooms. In addition, since in this article I am more concerned with what these teachers said rather than how they said it, in the interview excerpts that follow below, I have taken what Johnstone (2000, p. 115) refers to as a "play script" approach to transcription, and have not included details about features such as, for example, pauses, rising pitches, and stresses. I have also drawn from interviews with students and other stakeholders when necessary. 


\section{Science without Borders}

SWB was a scholarship programme launched in 2011 by the Brazilian federal government with the stated intention of promoting the consolidation, expansion and internationalization of science, technology, innovation and Brazilian competitiveness through international mobility and exchange (SCIENCE WITHOUT BORDERS, 2011a). Over the previous decade, numerous federal plans and policy documents expressed concerns over the rising national shortage of skilled human resources in STEM fields (SÁ; GREICO, 2015), and investment in the quality of academic preparation has been frequently promoted as a key strategy for addressing this problem and for the advancement of the Brazilian knowledge society (SCIENCE WITHOUT BORDERS, 2011b). As a proposed solution to this problem, SWB offered a range of fellowship streams including: doctoral (sandwich and full), post-doctoral, undergraduate (sandwich) (SCIENCE WITHOUT BORDERS, 2013a), but of the 100,000 scholarships pledged, the majority $(64,000)$ were reserved for undergraduate students as a 12-month year abroad, open to those who had completed between twenty and ninety percent of their required coursework at their home university at the time of their application. Student recipients of undergraduate scholarships were the focus of this larger study, and for their time abroad, the programme paid their tuition, international airfare, a monthly stipend to cover room and board, as well as a one-time grant for educational expenses such as textbooks and computers. In early conceptions of the programme, a key requirement of host institutions was that they be among the most highly regarded internationally for their specific area of knowledge and research according to the UK-published Times Higher Education and the QS World University Rankings (SCIENCE WITHOUT BORDERS, 2012). By sending the students to these prestigious institutions, the stated aim was to revolutionize the domestic research and development system by exposing Brazilian students and researchers to high levels of competitiveness and entrepreneurship (SCIENCE WITHOUT BORDERS, 2011a).

Early official documentation of the programme contains scant coverage of the question of language, beyond listings of required proficiency scores on the part of host institutions, and the occasional mention of opportunities for brief language upgrading upon arrival abroad (i.e., short courses, several weeks in length). This was despite the fact that the 
vast majority of SWB students would be studying in a second language, with well over fifty percent ultimately studying in English dominant nations (SCIENCE WITHOUT BORDERS, 2013b). At this stage of the programme, language appears to have been viewed as a simple conduit for the academic and practical knowledge in science and technology that would be acquired on the sojourn, rather than as a form of knowledge in its own right (PARK; WEE, 2012). While also largely viewing language as a conduit for other knowledge, in contrast to this seeming neglect of meeting second language requirements, Canada as one of the prospective host nations jockeyed to position itself as an attractive destination based on claims of expertise in second language education and academic preparation. As the International Education Division of Global Affairs, Canada articulates this self-perception and presentation: "Canada is a bilingual country and is considered a world leader in language training” (EDUCANADA, 2017). Canadian institutions of higher education, as well as governments at the provincial and federal levels moved quickly to secure as many SWB students as possible, and one of the partners of the federal government, CBIE, was enlisted as the primary manager for the programme in the country.

\section{Shifting grounds, emerging LPP}

The initial neglect of language on the Brazil side would only last briefly, as the programme managers at CAPES and CNPq (Conselho Nacional de Desenvolvimento Científico e Tecnológico, or the National Counsel for Scientific and Technological Development) soon found they were not meeting their target enrolment numbers, in large part due to a lack of students in higher education in Brazil with sufficient mastery of English (or other second languages for other destinations) (ENGBERG et al., 2014). This began a round of negotiations with host nations and institutions, where in some contexts such as the United Kingdom, the requirement of a minimum of 72 on the TOEFL iBT was reduced to as low as 42, a dramatic drop of 30 points (ESTADÃO CONTEÚDO, 2013). Other countries and higher education governing bodies around the world quickly followed suit, and in addition, limits set by Brazil on periods of foreign language study abroad prior to or concurrent with academic study were relaxed alongside the promise of the provision of funding for these extracurricular language courses (BRASIL, 2013). 
One solution on the home front was to launch the sister program Inglês sem Fronteiras (English without Borders) in December of 2012 (subsequently more inclusively branded Idiomas sem Fronteiras - Languages without Borders, in 2014), which began to provide language training for prospective CSF students prior departure on their sojourns. Related to the trouble in finding students with adequate second language proficiency for academic study abroad was that large numbers were signing up for the program and selecting Portugal as a destination. In 2013, the Brazilian Ministry of Education reported that to that date more than 32,000 students had chosen Portugal, and the volume of demand for this destination exceeded that of the vacancies in all the other participating countries combined (G1 NOTÍCIAS, 2013). As a result of this undesired focus on Portugal, which was being selected by students principally as a means to study in Portuguese and avoid learning a foreign language, the federal government decided to exclude the country from the program and all further calls directed the students to other destinations (VEJA, 2014). However, this decision meant that over three thousand applications from hopeful students that the various agencies had already received on recent calls were now ineligible. In order to keep these students in the running, and to allow the programme to continue to meet its target numbers, these students were given an opportunity to re-select a destination from a list including the United States of America, the United Kingdom, Australia, Canada, France, and Germany (IG, 2013). This group would become known as the Portugal cohort; for this cohort alone, proof of language proficiency in a second language would no longer be necessary to participate in the program, and students would have an opportunity to enrol in extended non-credit language training abroad for up to six months. As the then Minister of Education Aloízio Mercadante explained the closure of Portugal:

Nós não consideramos neste momento bolsas para Portugal para estimular os alunos na proficiência de outras línguas. Eles têm que enfrentar o desafio da segunda língua [At this time we are not considering scholarships to Portugal in order to stimulate the students to develop proficiency in other languages. They have to confront the challenge of a second language] (G1 NOTÍCIAS, 2013).

Language had thus moved to a far more central position in the SWB programme, particularly for this cohort, and it became necessary to quickly 
develop some LPP to reflect this need. Based on conversations with a senior administrator in the university international office, it appeared that this planning happened high up the hierarchical chain of command, with little consultation with institutions and language teaching professionals on the ground:

These students were reassigned to Canada, and the institutions were told that they had to offer their letters of admission with no conditions [...] The reality is it was sort of dictated to us and the students were not ready to proceed (2014-07-04: 12:26).

Comparably, a project manager at CBIE described the situation like this:

We inherited a cohort of students that was supposed to go to Portugal [...] which was quite challenging because these were the students who did not have the language skill necessary to go study in a language other than Portuguese. [...] I was not a part of these negotiations, but I know what was agreed at the end was that we could place them in an English language school only for a period of up to eight months (2014-09-24: 6:36)

In the case of the students and their teachers who are the focus of this study, the university language centre accepted over a hundred members of this cohort. Many of these students arrived in Canada with very low levels of English language proficiency. In the case of the student participants in this study, the majority tested into the lowest two levels of non-credit English language study at the host institution, where the lowest level is designed for absolute beginners. In order to meet this need for a highly compressed language learning timetable that was apparently negotiated far up the programme administrative power structure, the language centre management scrambled to adapt their curriculum for these students.

\section{Language testing and academic placements}

When I met with a student named Thiago, he showed me the timeline that he had initially been presented with: 
We got a letter from CBIE to explain. So it says

Oh, you are going to do four months of English course from September to December, and then you are going to be tested. And if you need more English you are going to do more English from January to April, and then from May to September you are going to do an internship organized by CBIE and that's it (Thiago, 2014-10-10: 43:34).

However, December came and went, with no news of test scheduling. He continued: 'In December we weren't tested. We didn't have the test. So in January we started to receive the mails from CBIE that we were going to do the test, the TOEFL" (Thiago, 2014-10-10: 46:22).

As it happened, early into their second semester in Canada, student members of the Portugal cohort began to receive notice that they would be writing the TOEFL test within the immediate or upcoming days and weeks (VEJA, 2014). A number of these students reported to the media that not only were they surprised at having to write the test prior to completing a significant portion of their English studies in Canada, but also that they were givenvery short notice of the test date-reporting insome cases that they were required to write the test only days after finding out that it was scheduled $(\mathrm{O}$ GLOBO, 2014). As a full-time teacher named Maria described it:

In February, the students at the lowest levels of our program received letters that they had to write the TOEFL exam with 48 hours notice'. The TOEFL exam is an exam that students study for months. They had only 48 hours to prepare themselves to write it. They had no chance and none of them got the TOEFL scores they were hoping to (2014-06-11: 6:01)

As a result of this short notice, many of the students were less than prepared to write the TOEFL test, and many received very low scores.

Several months later, as the semester was drawing to a close, about a hundred SWB students (around 80 in Canada, and 30 in Australia) received notice that they would be required to return home to Brazil and would not be permitted to continue academic activities in Canada. Shocked and surprised, the students organized a demonstration, which took place in front of the city hall in a large Canadian city and was covered extensively in the Brazilian media (FOLHA DE SÃO PAULO, 2014). These students argued that CAPES had not kept its promises to them, and by revising what they saw as the official schedule of language testing based on letters and other 
documents they had received at the beginning of their sojourn, had broken with the contract (IG, 2014).

The subsequent debate about the plight of these students took place in both the Brazilian mainstream media and social media, and overwhelmingly suggested that the reason these students were being sent home was a result of their poor scores on these language tests (IG, 2014; O GLOBO, 2014; VEJA, 2014). Discussions on social media saw commentators blaming the students for not studying English harder while on their sojourn, while the students defended themselves by challenging the fairness of the timing of the TOEFL tests as described above. In this way, language testing and language aptitude emerged as the discursive field on which these students' performance as sojourners abroad was to be evaluated, and the predicament of these students was largely framed as a language issue. A year later, official government documents reviewing the programme came to similar conclusions, presenting the case of these students being recalled to Brazil as a result of their failure to successfully learn English in the time allocated (e.g., BRASIL, 2015, p. 44-45).

Drawing on this brief narrative of the timeline of the experiences of this cohort of CSF students, here is a summary of the LPP processes at work in this case. An exception was made that they would be able to travel abroad without requisite levels of language proficiency. This came with the caveat that they would only be able to engage in language study for eight months, during which they would be tested and, if successful, placed in subsequent programming. However, this language testing took place in less than ideal conditions, with a lack of transparency not only to students, but to teachers and other stakeholders in terms of the scheduling of these tests. Their scores on these tests then played a key gatekeeping role in their success in securing an academic placement. Success or failure at passing this hurdle was largely attributed to the efforts of the individual students, and questions surrounding fairness of both the design of the language training and the test scheduling and notification process were largely ignored. In the next section, I turn to how the teachers in this particular language centre responded to this testing regime imposed on their students specifically, and to the LPP conducting the Portugal cohort from the top down more generally. 


\section{Teacher responses to LPP}

Some of the first concerns the teachers had with the language centre taking on a large group of members of the Portugal cohort were with the proposed timeline and compressed curriculum. As a full-time senior teacher named Alison explained it,

The Brazilian government decided 'OK, look, these students will study for eight months and they'll go to university'. I mean, I don't know what linguist they consulted with but that's not a reasonable time to tell someone at Level 1 [the lowest level offered at the centre] that "Oh, you'll go to university in eight months. Like no. Our programme takes a year and a half to finish" (2014-06-04: 10-28).

A part-time teacher named Wendy, working from contract to contract, echoed this sentiment about the plight of the students in even stronger words:

They were absolutely set up to fail. Because, I mean, any language expert who has done any research understands that it takes two to seven years to acquire a language to be able to function at the same level as a native speaker (2014-07-15: 38:55).

Yet despite their concerns about this study schedule, the teachers endeavoured to focus on what they saw as the positive aspects to this situation. Wendy explained:

The pros of working with these students is that as a whole they were very driven and dedicated. I've worked with a number of groups of students who do thirty hours a week and complain constantly, and these students didn't seem to do that. They seemed very driven towards the end goal, which was starting their university programmes (2014-07-15: 3:35).

Another part-time faculty member named David made a similar observation. When I expressed my own reservations about the eight-month schedule in our conversation, he countered my comments.

I: Do you think that eight months is possible...?

D: I think it's possible. I mean, I'm a big believer in the impossible. I mean, I saw it being possible. I had students who couldn't speak anything writing an essay at the end of the first semester. I know it is possible because it did happen. With my students anyways (201501-13: 38:34). 
Alison provided a cautious qualification to a similar question, stating that "for a specific type of learner it works" (2014-06-04: 22:03).

Yet, despite this belief in the students' abilities, for the most part teachers were frustrated by what they perceived as a lack of institutional support assisting them in implementing these challenging curricular demands. David remarked that "There were dollar signs in everyone's eyes, but there was no real direction in terms of how they were going to get this many students through the programme" (2015-01-13: 23:50). Complaints about the lack of support were even greater when directed specifically at the conditions under which the TOEFL testing procedures were revealed and scheduled. Again, David described the situation.

Nobody knew what was going on. So CAPES basically got them all to do a TOEFL test. It was their last and only chance and they didn't tell them it was their last and only chance. They didn't tell [the school and the teachers] that they were doing a TOEFL test. The students just said to us, 'Yeah, we are going to do a TOEFL test and it's going to be next Thursday'. So that kind of thing, all the stuff we had built, all that motivation, all that positivity, gone. In one week it was gone (2015-0113: 17:37).

Alison corroborated this state of affairs, as well as the lack of notification of changes to the programme: "I find out most of my information from the students" (2014-06-04: 7:15). Speaking more on the issue of transparency for the entire population of the centre, including both the students and the teachers, David lamented, "What they could have done was just do a general assembly. Why didn't they do that, and why didn't they have any staff meetings about it [...] they couldn't because [the centre] never did have control over the information" (2015-01-13: 28:36).

Discussing the general morale in his classes after the TOEFL tests were first announced, he said:

It went from a one hundred percent attendance rate to less than forty percent. And I said, 'Guys, I'm just the teacher. I'm being contracted to do this'. There's nothing I can do about this. And there was no administrative support for us, the teachers. I think there was a moment where they were just like, let's get through with it. At that point it was just about the money (2015-01-13:18:32). 
Because the majority of the conversations I had with these teachers took place several months after the SWB students had completed their time at the language centre (as opposed to my conversations with the students, which took place regularly throughout their time in Canada), in their reflections on what went wrong, they also suggested some ways in which they would have changed their practices had they had more knowledge and advance warning of what was meant to happen for these students. Wendy, in particular, had a number of ideas. Speaking about the TOEFL tests, she explained,

From an instructor perspective, what I would have liked to have seen is giving these students more support in taking the TOEFL if that is the end goal $[\ldots]$ I would rather see them focus on getting that score. Now that's a contentious opinion I know because a lot of people do not agree with teaching to a test, but we have to think about what the ultimate goal is (2014-07-15: 12:32).

Thinking about the programme and the broader curricular content that was provided to these students, she also mused about the appropriacy of English language training within a general academic, or EAP (English for Academic Purposes) framework, given the fact that these students were all studying in science and technology-related fields, that they were keen to get started on these studies, and prepared to work hard to reach this objective.

These were the first students as a whole who would call us out and say,

you know what, the note-taking strategies that you are teaching me do not apply to my major [...] why are you wasting my time learning about the psychology of love when I need to learn terminology that is relevant to my major to help me succeed when I start my programme? And I think that was really valid because they called us out on that, maybe they shouldn't have been streamlined into this general programme, maybe it should have been more of an ESP programme [English for Specific Purposes] to focus on their specific needs and bring in ESL instructors who have a background in the sciences, to help them with whatever they were focusing on (2014-07-15: 24:45).

These comments from teachers add an additional layer of understanding to the LPP processes of the SWB programme as described in the previous section and based on policy documents and media reports. In this case, it appears that a large number of the policy decisions - i.e., 
the duration of English language study, the scheduling of the testing, happened with very little consultation with teachers and second language education professionals in the university. While the modified curriculum was established in-house, these teachers had doubts about the appropriacy of these curricular choices, and how they fit in with the larger design of the SWB programme. These doubts were further aggravated by the lack of transparency regarding the various stages of the programme. To be clear, I do not wish to cast any blame on these teachers or suggest that they could or should have done things differently with their own classes. In the last section of this article, I move from the specificity of this situation towards a more general reflection on how a dynamic LPP process such as this creates considerable challenges for critical language teachers in their practice and suggest some possible approaches for action in cases where scant wiggle room is seemingly on offer for teachers.

\section{Negotiating LPP in critical language teaching}

In his later work, Foucault (1990, p. 92) offers an understanding of power as "the multiplicity of force relations immanent in the sphere in which they operate" and as "the process through which, through ceaseless struggles and confrontations, transforms, strengthens, or reverses them". As such, it is important to note that within this model, there is no outside in terms of relations of power, and that "resistance is not in a position of exteriority with respect to power" (DAVIDSON, 2011, p. 27). Foucault (2009, p. 201) refers to acts of resistance as examples of "counter-conduct", which he defines as "the sense of struggle against the processes implemented for conducting others". Yet, because this struggle is relational to these other processes, this does not necessarily mean that acts of counter-conduct or resistance are only reactive or epiphenomenal; rather, within the Foucauldian conception of power relations, they have the same potential or productive capacity as all possible actions (id., 1990). In her review of the evolution of critical pedagogy in EAP contexts, Haque makes a similar argument, and drawing on Foucault's contemporary Michel de Certeau, makes a helpful theoretical distinction between strategies and tactics, with strategies tending to be more overt, and emanating from those who "control the space and/ or terms of engagement", contrasted with tactics used by other agents, such as the subjects of these strategies, as "an action in hostile territory and 
opportunistic action taken when you do not set the terms of engagement" (HAQUE, 2007, p. 100). This thinking resonates with the conditions for the language teachers in the situation presented thus far in this article. As holders of less power, relative to other agents and stakeholders in the LPP process of SWB, these teachers were considerably constrained, appearing to have little opportunity to adjust the terms of engagement and the overt strategies formulated by other agents in the LPP assemblage (i.e., the curriculum, the testing procedures and scheduling) which they were tasked with delivering. This was perhaps especially the case for those teachers who were working part-time on a temporary contract basis and were therefore that much more precariously positioned than their full-time colleagues within the language centre.

While the features of this particular case have their own nuances, these types of conditions for language teachers in higher education in Canada are becoming increasingly common as the enrolment numbers of international students continue to rapidly increase (STEIN; ANDREOTTI, 2016). What then can language teachers who endeavour to take a critical approach to their practice do, in order to help their students critically investigate the power relations in society they find themselves in generally (HAWKINS; NORTON, 2009), as well as specifically in terms of the LPP that designs their programming?

Taking up the notion of tactics as described above, Haque (2007, p. 102) suggests "the cultivation of a steadfast vigilance, on guard for any opportunistic possibilities of action that must be seized as they arise". As an example, she describes the situation of one English language unit struggling with other departments in the university over recognition of the English language proficiency of Indian nationals. In order to assist several students in their application processes, one of the language teachers telephoned the Indian embassy to request official documentation of the official status of English in India, for the students to submit with their admissions packages. Similarly, one of the teachers in my study spoke off the recording with me of placing calls to CBIE on behalf of students to request additional information about test scheduling, and subsequently, to request clarification of information about the admissions and acceptance processes for several students' prospective academic placements. However, this type of action is of course not without its own problems in terms of sustainability, and in terms of adding additional labour that is far outside the remit of language 
teachers who are often overworked and undercompensated. Yet, the nature of tactics such as these is that they are for the most part temporary and often improvised moves rather than being more regular and regulated in the way that strategies are. Another example of a possible tactic in the case of the SWB students could be for a teacher to push at the edges of the curriculum as much as possible to address student needs. As the excerpt from interviews with Wendy included above suggest, with greater advance warning, it perhaps would have been possible to improvise a brief module on TOEFL test preparation and insert it into the classes prior to when the students were scheduled to write their tests, and to assist them otherwise in preparing for their test taking as much as possible. Similarly, in the case she cited of students complaining that the psychology-based content in the language course she was teaching did not provide them with an opportunity to develop their knowledge of technical terminology in their chosen field, a possible work-around could be devising one or more tasks which allowed the students to address their own specific vocabulary needs. Or more generally, to substitute as many texts as possible with those that students found meaningful for their own fields of study, or perhaps even selected themselves. These are just a few brief examples, for as Haque (ibid.) notes, tactics are by definition unstructured and spontaneous, and as a result, it is not possible to articulate a singular plan of action or a general checklist of them.

Perhaps the most valuable form of counter-conduct that critical language teachers might engage with in situations such as these is to maintain a sort of critical policy awareness at all times, and practice attentiveness in regards to the LPP conditions of their students' language learning and of their own contributions towards it. This is a topic that could be more fully incorporated into critical language teacher training, helping novice teachers develop tools to be as aware as they can of the LPP landscape in which they are working, and in turn, to make efforts to share this awareness with their students, as well as to view the students as allies and as potential sources of information about LPP as well.

\section{Conclusion}

In this paper I have described one recent situation where dynamic LPP conditions presented a range of unique challenges for language teachers 
both in terms of preparing students for academic study in a second language, and in terms of taking a critical approach to their own practices. In the case of the SWB programme, a frequently shifting and often opaque LPP terrain found teachers often left out of planning and policy-making processes, despite the fact that the classroom typically constitutes ground zero of LPP implementation. The language teachers at this Canadian university were required to negotiate scant wiggle room in regards to the duration of the period of language study, and the testing required of these students with little advance warning. They questioned the possibility of successful language learning, given what they perceived as the often-unreasonable expectations the programme placed on these students. As an example of the interface between LPP and CLT, and the considerable constraints of a policy regime imposed on teachers both from the top down and from a range of sources, in this paper I have suggested bottom-up tactics of counter-conduct as creative and often improvised approaches to LPP conditions such as these, and called for a greater incorporation of critical LPP awareness into language teacher training curricula.

\section{References}

ALTBACH, P. G. Globalization and the university: realities in an unequal world. In: FOREST, J. J. F.; ALTBACH, P. G. (Ed.). International handbook of higher education. Dordrecht: Springer, 2007. p. 121-139.

BLOMMAERT, J. The sociolinguistics of globalization. Cambridge: Cambridge University, 2010.

BRASIL. Conselho Nacional de Educação. Documento técnico contendo estudo analítico, teórico e metodológico sobre o impacto e a organização do Programa Ciência sem Fronteiras nas políticas públicas da educação superior. Brasília, DF: MEC, 2013. Available from: <https://goo.gl/R21Aam>. Retrieved on: 28 May 2017.

BRASIL. Senado Federal. Comissão de Ciência, Tecnologia, Inovação, Comunicação e Informática. Programa Ciência Sem Fronteiras. Relatório de avaliação de políticas públicas. Brasília, DF, 2015. Available from: < https://goo.gl/Dg2JnU>. Retrieved on: 28 May 2017.

CANAGARAJAH, S. Reconstructing local knowledge, reconfiguring language studies. In: CANAGARAJAH, S. (Ed.). Reclaiming the local in language policy and practice. Mahwah: Lawrence Erlbaum, 2005. p. 3-24. 
CANAGARAJAH, S. Ethnographic methods in language policy. In: RICENTO, T. (Ed.). An introduction to language policy: theory and method. Malden, MA: Blackwell, 2006. p. 153-169.

CHUN, C. W. Power and meaning making in an E AP classroom: engaging with the everyday. Bristol: Multilingual Matters, 2015. Doi: https://doi.org/10.21832/9781783092956

DAVIDSON, A. I. In praise of counter-conduct. History of the Human Sciences, Thousand Oaks, v. 24, n. 4, p. 25-41, 2011.

DIALLO, I.; LIDDICOAT, A. J. Planning language teaching: an argument for the place of pedagogy in language policy and planning. International Journal of Pedagogies and Learning, Abingdon, v. 9, n. 2, p. 110-117, 2014.

EDUCANADA. Why study in Canada? Ottawa, 6 Jul 2017. Available from: < https:/ / goo.gl/wKRuuE>. Retrieved on: 28 May 2017.

ENGBERG, D. et al. The rationale for sponsoring students to undertake international study: an assessment of national student mobility scholarship programmes. Manchester: British Council, 2014. Available from: <https://goo.gl/6sLVid $>$. Retrieved on: 24 May 2017.

ESTADÃO CONTEÚDO. Após reprovação alta, nivel de inglês exigido para bolsas será menor. [S.1], 7 Feb 2013. Available from: < https://goo.gl/uqT1XJ>. Retrieved on: 25 Jun 2018.

FOLHA DE SÃO PAULO. Bolsistas brasileiros no Canadá questionam chamado de retorno do governo. São Paulo, 9 Abr 2014. Available from: <https://goo.gl/xeuvUd>. Retrieved on: 25 Jun 2018.

FOUCAULT, M. The history of sexuality: an introduction. New York: Vintage, 1990. v. 1.

FOUCAULT, M. Security, territory, population: lectures at the Collège de France 19771978. New York: Picador, 2009.

G1 NOTÍCIAS. Portugal será excluido do Ciência sem Fronteiras, diz Mercadante. Brasília, DF, 24 Abr 2013. Available from: <https://goo.gl/PkzwXj>. Retrieved on: 25 Jun 2018.

HAQUE, E. Critical pedagogy in English for academic purposes and the possibility of 'tactics' for resistance. Pedagogy, Culture \& Society, Abingdon, v. 15, n. 1, p. 83106, 2007.

HAWKINS, M.; NORTON, B. Critical language teacher education. In: BURNS, A; RICHARDS, J. (Ed.). Cambridge guide to second language teacher education. Cambridge: Cambridge University, 2009. p. 30-39. 
IG. Exigência de lingua estrangeira cai e intercambistas podem escolher país. São Paulo, 4 Mar 2013. Available from: <https://goo.gl/SRBJ6r>. Retrieved on: 25 Jun 2018.

IG. Alunos sem fluência em inglês são excluidos do programa Ciência sem Fronteiras. São Paulo, 10 Abr 2014. Available from: < https://goo.gl/QwNLiU>. Retrieved on: 25 Jun 2018.

JOHNSON, D. C. Language policy. New York: Palgrave Macmillan, 2013.

JOHNSON, D. C.; JOHNSON, E. J. Power and agency in language policy appropriation. Language Policy, Rotterdam, v. 14, n. 3, p. 221-243, 2015.

JOHNSTONE, B. Qualitative methods in sociolinguistics. Oxford: Oxford University, 2000.

LUKE, J. R. Higher education policy, English language learning and language policy: an ethnography of Brazilian STEM scholarship students in Canada. 2017.356 f. Thesis (Doctorate in Applied Linguistics) - Department of Languages, Literatures, and Linguistics, York University, Toronto, 2017.

MENKEN, K. English learners left behind: standardized testing as language policy. Clevedon: Multilingual Matters, 2008. Doi: https://doi.org/10.21832/9781853599996 PARK, J. S-Y.; WEE, L. Markets of English: linguistic capital and language policy in a globalizing world. New York: Routledge, 2012.

PENNYCOOK, A. Critical applied linguistics: a critical introduction. Mahwah: Lawrence Erlbaum, 2001.

O GLOBO. Capes manda 110 bolsistas do Ciência sem Fronteiras voltarem ao Brasil por nivel baixo em inglês. Rio de Janeiro, 9 Abr 2014. Available from: <https://goo. gl/2neQmZ>. Retrieved on: 25 Jun 2018.

RAMANATHAN, V.; MORGAN, B. (Ed.). Tesol and policy enactments: perspectives from practice. Tesol Quarterly, Alexandria, v. 41, n. 3, p. 447-463, 2007.

SÁ, C.; GREICO, J. International collaboration in Brazilian higher education. Frontiers of Education in China, Leiden, v. 10, n. 1, p. 7-22, 2015.

SCIENCE WITHOUT BORDERS. O programa: o que é?. Brasília, DF, 24 Aug 2011a. Available from: <https://goo.gl/z5mmBS>. Retrieved on: 26 May 2017.

SCIENCE WITHOUT BORDERS. Objetivos. Brasília, DF, 13 Dec 2011b. Available from: <https://goo.gl/eFa4YZ>. Retrieved on: 25 May 2017.

SCIENCE WITHOUT BORDERS. Canadá: graduação. Brasília, DF, 21 Apr 2012. Available from: < https://goo.gl/HDSdzY>. Retrieved on: 26 May 2017. 
SCIENCE WITHOUT BORDERS. Metas. Brasília, DF, 22 Jan 2013a. Available from: <https://goo.gl/4mKBj2>. Retrieved on: 25 May 2017.

SCIENCE WITHOUT BORDERS. Painel de controle. Brasília, DF, 18 Apr 2013b. Available from: < https://goo.gl/19LpqB > . Retrieved on: 28 May 2017.

SHOHAMY, E. Language policy: hidden agendas and new approaches. London: Routledge, 2006.

STEIN, S; ANDREOTTI, V. O. Cash, competition, or charity: international students and the global imaginary. Higher Education, Rotterdam, v. 72, n. 2, p. 225 239, 2016.

STRITIKUS, T. T. The interrelationship of beliefs, context, and learning: the case of a teacher reacting to language policy. Journal of Language, Identity, and Education, Abingdon, v. 2, n. 1, p. 29-52, 2003.

TOLLEFSON, J. W. Critical theory in language policy. In: RICENTO, T. (Ed.). An introduction to language policy: theory and method. Oxford: Blackwell, 2006. p. 42-59. VARGHESE, M. et al. Theorizing language teacher identity: three perspectives and beyond. Journal of Language, Identity, and Education, Abingdon, v. 4, n. 1, p. 21-44, 2005.

VEJA. Porfalta de proficiência em inglês, 110 bolsistas do Ciência sem Fronteiras vão voltarpara o Brasil. [S.1], 9 Abr 2014. Available from: <https://goo.gl/3U6wnw>. Retrieved on: 25 Jun 2018.

Data de submissão: 22/11/2017. Data de aprovação: 21/04/2018. 